\title{
HELYI HATALOM ÉS MARKETING
}

\author{
(Local power and marketing) \\ TÓTH ANTAL
}

A helyi hatalom és a marketing kapcsolatrendszerében mai felfogásunk szerint kétségtelenül vannak olyan mezók, amelyek értelmezésére viszonylag tág tudományos apparátus áll a rendelkezésünkre. Ugyanakkor egyáltalában nem nélkülözhetünk olyasfajta gyakorlati megközelítéseket, amelyek nélkül e sajátos módszertan, helyesebben ,világlátás" semmit sem érne, alkalmazhatósága rövid távon ,lenullázódna”. Valójában miről is van szó?

A térségi marketing létjogosultságát, társadalmi hasznosságát ma már senki sem vitatja: a terület- és telepủlésfejlesztési szakmai közvélemény szerte a világon nemcsak elfogadja, hanem a konkrét elemzömunka mindennapjaiban is széles körben alkalmazza a diszciplína bevált empirikus módszereit. Ebből a szempontból az „ezoterizációs folyamat” kiemelkedó állomása volt az 1983-ban elfogadott Torremolinosi Charta, amely minden vonatkozásban új perspektivába helyezte a szóban forgó metodika fontosságát a terület- és településfejlesztésben.

Ami a hazai vonatkozásokat illeti, itt mindenképpen az 1989-es rendszerváltás volt az, amely lehetővé tette az alkalmazhatóság konkrét kérdéseinek a felvetését, mivel az önkormányzatiság immár „életközeli” megjelenése és mindennapi társadalmi megélése mind nagyobb esélyt adott a lokális szuikségletek tudományos, operacionalizált elemzésének, azok „agypolitikai” és helyi politikai dimenzióinak kialakításához. Ugyanakkor a ,prózai praxis" nagyon is konkrét korlátokat állít a térségi marketing kutatási módszereinek széles körú alkalmazása elé, pedig az irányukban megjelenỏ döntéshozói, döntéselókészítői szükségletek nem csupán megérettek, hanem túlérettek is bizonyos vonatkozásban. A továbbiakban érdemes lenne áttekinteni azokat a politikai-gazdasági tényezőcsoportokat, amelyek napjainkban determinálják e mozgásfolyamatok kibontakozását.

E sorok írójának tapasztalatai szerint a térségi marketing módszerek gyakorlati alkalmazását, lokális döntési folyamatokba való beépítését elsősorban azok az önkormányzatok igénylik, amelyeknek az átlagosnál lényegesen fejlettebb döntési kultúrájuk van, s amelyek felismerték azt, hogy a lakossági igények ,piacosodása" nem más, mint az ónkormányzatiság lényegének gyakorlati kifejeződése. Ebben a kontextusban viszont a lakossági szükségletek, a lakosság érdekstruktúráinak döntésekben való megjelenése akkor is alapvető kérdés, amikor - tekintettel az igencsak korlátos pénzügyi mozgástérre - látszólag nincs esély ezen szükségletek figyelembevételére.

A helyi telepủlésfejlesztési tervezetek, koncepciók participációs és szükségletkommunikációs jellegü lakossági „megmerítése" csakis akkor lehet hatékony, ha világos és egy- 
értelmü, a térség „értékesítési szcenárióit” is magában foglaló marketing koncepció áll a döntéshozók rendelkezésére. Ennek kidolgozása is csupán akkor lehetséges, ha az önkormányzati testület, a polgármester és a kutatást-elemzést végrehajtó kutatási mủhely között minimális összhang van a fejlesztés céljait illetően. Ez a konszenzus álláspontunk szerint akkor alakul ki a leggyorsabban, ha a projektum konkrét gazdasági, illetőleg gazdaságfejlesztési elemeket is tartalmaz, azaz célrendszerében a profit és non-profit jellegü elemek egyaránt (és meglehetősen pregnáns formában) jelen vannak.

Mindazonáltal, tapasztalataink szerint a participációs és szükségletkommunikációs jelleg csak abban az esetben nyer gyakorlati tartalmat, ha a helyi lakosság a projekt minden fázisát nemcsak követi, hanem aktívan be is kapcsolódik annak lebonyolításába. A jelek szerint ugyanis maga a marketing stratégiai folyamat is fontos etápja a helyi politikai legitimáció, a döntéshozói célokkal való azonosulás kialakulásának. Márpedig ebben a vonatkozásban a helyi döntéshozónak egyszerủen nincs jobb eszköze céljai megismertetésére, elképzelései köztudatba való beültetésére.

Természetesen egy olyan történelmi helyzetben, amikor ,se hajó, se víz" nincsen, a települési-térségi marketing sincsen könnyủ helyzetben akármennyire is kristálytiszta metodikával, eszköz- és célrendszerrel operál. Ugyanakkor eléggé világosan felrajzolhatók azok a kondíciók, amelyek mentén a projekt lezárásaként kialakult marketing-stratégia sikeres végrehajtása az önkormányzat, illetve a település lakossága vonatkozásában követelményként megfogalmazható. Ezek a feltételek a következők:

a) Adaptációs képesség

Mind az önkormányzatnak, mind a település lakóinak gyorsan és hatékonyan el kell sajátítaniuk, majd a gyakorlatban is alkalmazniuk kell azokat a marketing eszközöket és fogásokat, amelyeket számukra a stratégia megfogalmaz. Ennek megfelelöen - a belsỏ kommunikáció megszervezésén túl - a telepulés teljes külsó kapcsolatrendszerét úgy kell kialakítani, illetve átalakítani, hogy az megfeleljen az alapvetó marketing céloknak. Adott esetben el kell felejteni azokat a testvérvárosi, testvérközségi, kistérségi stb. kapcsolatokat, amelyek nem viszik elöre a település ügyét, ám ezzel párhuzamosan olyan új partnereket kell keresni, amelyekkel való együttmúködés a célrendszerben megfogalmazottak irányába mutatnak.

b) Rugalmasság

A telepulési önkormányzatnak rendkívül rugalmasnak kell lennie a belsỏ erőforrások felkutatásában és hasznosításában. Ezzel párhuzamosan egyfajta belső „erőforrásmonitoringot” kell kiépítenie és müködtetnie annak érdekében, hogy a település gazdasági és humán erőforrásai bármikor bevethetöek legyenek a marketing célok végrehajtására.

c) Komplexitás

Az operációs szakaszban is meghatározó jelentősége van a települési marketing egyes elemei (PR, reklám, direct mail, szükségletkommunikáció stb.) összehangolt és komplex alkalmazásának. Legjobb, ha ezekre a részterületekre önálló forgatókönyvek és intézkedési tervezetek születnek, amelyek következetes végrehajtása érdekében lehetőleg egyszemélyi felelősöket kell kijelölni. 
d) Célirányosság

E kritérium jegyében elsősorban az alapprioritások végrehajtására és nem „mellékösvények" felkutatására és kitaposására kell koncentrálni az operációs periódusban. Ez viiszonylag könnyen kalibrálható feladat, hiszen a jó marketing-stratégia egyértelmú fontossági sorrendet állít fel a végrehajtandó feladatok vonatkozásában.

e) Erőforrásallokációs-képesség

Ennek a követelménynek a figyelembevétele és következetes betartása az egyik legoptimálisabb eszköze a marketing-startégia és a gazdasági alapú fejlesztési stratégia hatékonysági mutatói összevetésének. Ugyanis bármennyire is fejlett az önkormányzat belső és külsó lobbizási technikája, ,alkultúrája”, csak azokat az eröforrásokat lehet optimálisan felhasználni, amelyekre ténylegesen szüksége van a településnek, amelyeket a helyi társadalom és gazdaság hatékonyan képes felhasználni. 


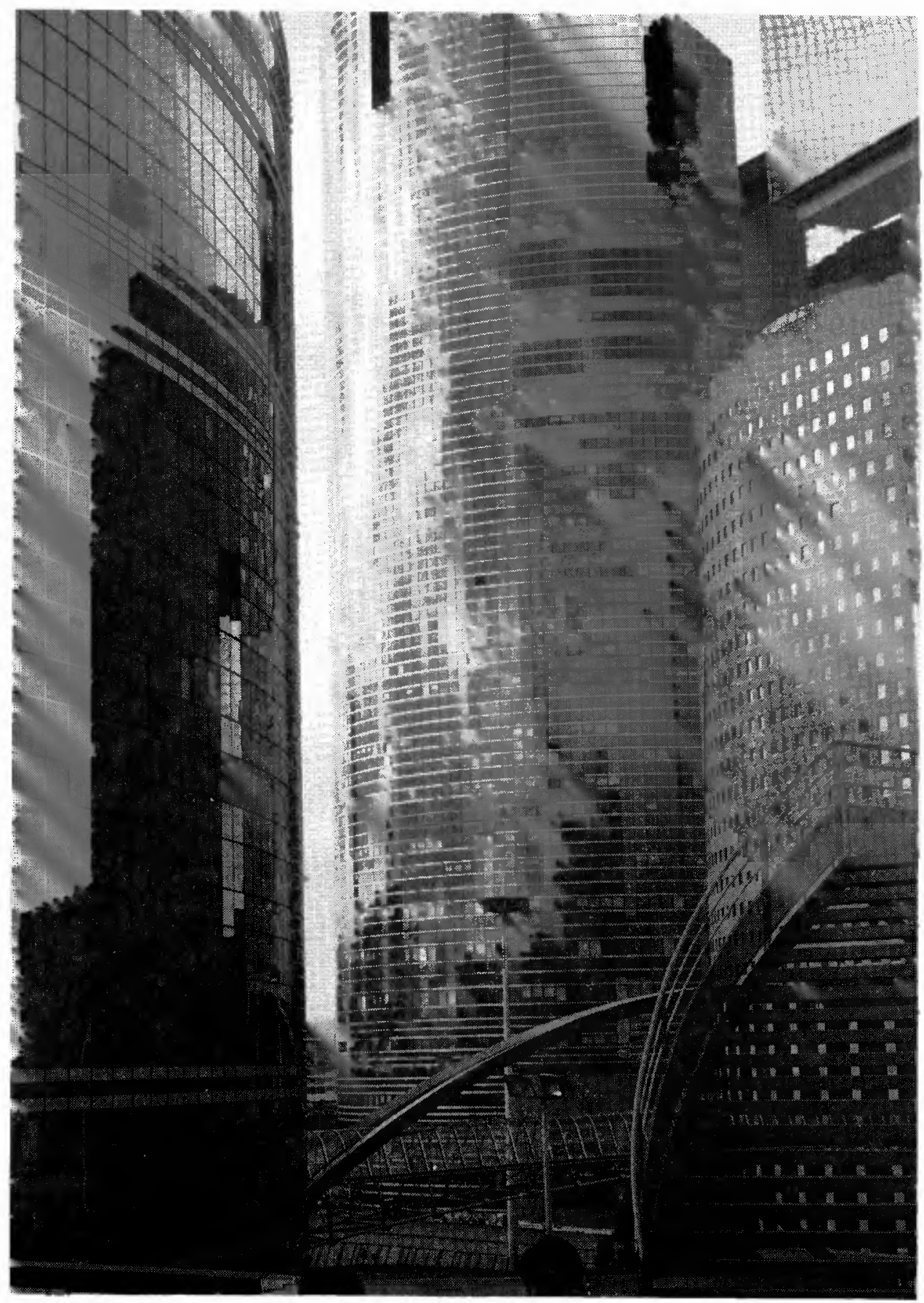

A modern Párizs - a Défense negyed

(Fényképezte: Kraftné Somogyi G.) 